\title{
APLIKASI PEMBUATAN JADWAL SIDANG KERJA PRAKTEK, PRA SIDANG, DAN SKRIPSI DENGAN ALGORITMA GREEDY SEKOLAH TINGGI TEKNOLOGI INDONESIA TANJUNGPINANG
}

\author{
${ }^{1}$ Herman, ${ }^{2}$ Liza Safitri
}

Sekolah Tinggi Teknologi Indonesia, Jurusan Teknik Informatika e-mail : ${ }^{1}$ whynotsam8@gmail.com, ${ }^{2}$ lizasafi3@gmail.com

\begin{abstract}
ABSTRAK
Sekolah Tinggi Teknologi Indonesia Tanjungpinang merupakan sebuah tempat institusi atau perguruan tinggi yang mengfokuskan pendidikan di bidang informatika dan sistem informasi pada komputer. Sistem penjadwalan sidang yang sedang dilakukan oleh Sekolah Tinggi Teknologi Indonesia Tanjungpinang bersifat secara manual sehingga sering terjadinya kesalahan dan kelambatan dalam acara sidang. Untuk mengatasi masalah-masalah yang akan terjadi, maka dibutuhkan sebuah aplikasi yang terkomputerisasi untuk mempermudah dalam proses pembuatan jadwal sidang
\end{abstract}

Dalam melakukan penelitian ini, metodologi yang digunakan adalah metode waterfall yang terdiri dari rekayasa sistem, analisis, desain, implementasi, pengujian dan pemeliharaan. Tahap analisis menggunakan metode terstruktur denganFlowmap dan DFD. Hasil dari penelitian ini adalah dibangunnya suatu perangkat lunak untuk mengolah data service yang dibuat dengan bahasa pemograman ASP.NET dan Microsoft SQL Server. Metode yang digunakan dalam aplikasi ini adalah Algoritma Greedy.

Diharapkan dengan adanya aplikasi yang dibangun ini akan mempermudah pihak Sekolah Tinggi Teknologi Indonesia Tanjungpinang dalam proses pembuatan jadwal sidang dan mahasiswanya dapat mendaftarkan diri mengikuti sidang lebih mudah.

Kata Kunci : Sekolah Tinggi Teknologi Indonesia Tanjungpinang, pengolahan data, aplikasi, penjadwalan, algoritma greedy, asp.net

\section{PENDAHULUAN}

Dari waktu ke waktu pengetahuan dan teknologi semakin mengalami kemajuan. Seiring dengan berkembangnya teknologi tersebut, manusia terus berusaha untuk meningkatkan kreatifitas dan aktifitasnya dengan menggunakan alat pembantu yang canggih yaitu teknologi komputer. Dengan 
kecanggihan teknologi tersebut, pekerjaan dapat di selesaikan dengan lebih cepat, akurat dan efisien.

Komputer merupakan suatu alat serba guna yang dapat digunakan untuk melakukan berbagai fungsi. Fungsi utama komputer adalah melakukan pengolahan data, sehingga dapat membantu manusia dalam menyajikan informasi secara cepat, tepat, dan akurat. Secara umun diketahui bahwa sumber informasi itu adalah kumpulan data. Namun, komputer tetap membutuhkan user untuk menjalankan sistemnya.

Sekolah Tinggi Teknologi Indonesia merupakan sebuah tempat edukasi yang mengajar mahasiswa-mahasiswa dibidang teknologi informasi khususnya bagian software atau pemrograman.

Dari latar belakang tersebut penulis mempunyai gagasan untuk membangun sebuah aplikasi yang dapat membantu Sekolah Tinggi Teknologi Indonesia khususnya bagian pembuatan jadwal sidang kerja praktek, prasidang, dan sidang akhir skripsi di kampus agar tidak terjadi bentrokan antar dosen dengan judul Aplikasi Pembuatan Jadwal Sidang KP, Pra sidang, dan Skripsi dengan algoritma Greedy Sekolah Tinggi Teknologi Indonesia Tanjungpinang.

\section{KAJIAN PUSTAKA}

2. Aplikasi

Perangkat lunak aplikasi (software application) adalah suatu subkelas perangkat lunakkomputer yang memanfaatkan kemampuan komputer langsung untuk melakukan suatu tugas yang diinginkan pengguna. Biasanya dibandingkan dengan perangkat lunak sistem yang mengintegrasikan berbagai kemampuan komputer, tapi tidak secara langsung menerapkan kemampuan tersebut untuk mengerjakan suatu tugas yang menguntungkan pengguna. Contoh utama perangkat lunak aplikasi adalah pengolah kata, lembar kerja, dan pemutar media.

Beberapa aplikasi yang digabung bersama menjadi suatu paket kadang disebut sebagai suatu paket atau suite aplikasi (application suite). Contohnya adalah Microsoft Office dan OpenOffice.org, yang menggabungkan suatu aplikasi pengolah kata, lembar kerja, serta beberapa aplikasi lainnya. Aplikasi-aplikasi dalam suatu paket biasanya memiliki antarmuka pengguna yang memiliki kesamaan sehingga memudahkan pengguna untuk mempelajari dan menggunakan tiap aplikasi. Sering kali, mereka memiliki kemampuan untuk saling berinteraksi satu sama lain sehingga menguntungkan pengguna. Contohnya, suatu lembar kerja dapat 
dibenamkan dalam suatu dokumen pengolah kata walaupun dibuat pada aplikasi lembar kerja yang terpisah.

3. Penjadwalan

Penjadwalan dapat didefinisikan sebagai pengalokasian sumber daya dalam jangka waktu tertentu untuk melakukan serangkaian tugas (Baker, 1974). Menurut Morton (1993), penjadwalan adalah proses pengorganisasian, pemilihan, dan penentuan waktu penggunaan sumbersumber untuk mengerjakan semua aktivitas yang diperlukan yang memenuhi kendala aktivitas dan sumber daya. Menurut Baker (1974) yang juga sejalan dengan Morton (1993), terdapat dua jenis kendala yang seringkali ditemukan dalam masalah penjadwalan, yaitu:

1. Keterbatasan teknologi urutan pengerjaan job atau routing (kendala aktivitas) .

2. Batas kapasitas sumberdaya yang tersedia (kendala sumberdaya).

Dapat dikatakan bahwa solusi terhadap masalah penjadwalan adalah setiap solusi yang fisibel pada daerah yang memenuhi kedua kendala tersebut (feasible region).

\section{Algoritma Greedy}

Algoritma adalah langkah dalam mencari solusi atas sebuah masalah. banyak sekali algoritma yang dapat kita gunakan dalam membangun sebuah program, salah satunya adalah algoritma greedy.

Algoritma greedy merupakan metode yang paling populer untuk memecahkan persoalan optimasi. Greedy sendiri diambil dari bahasa inggris yang artinya rakus, tamak atau serakah. Prinsip algoritma greedy adalah: "take what you can get now!".

Algoritma greedy merupakan jenis algoritma yang menggunakan pendekatan penyelesaian masalah dengan mencari nilai maksimum sementara pada setiap langkahnya. Nilai maksimum sementara ini dikenal dengan istilah local maximum. 


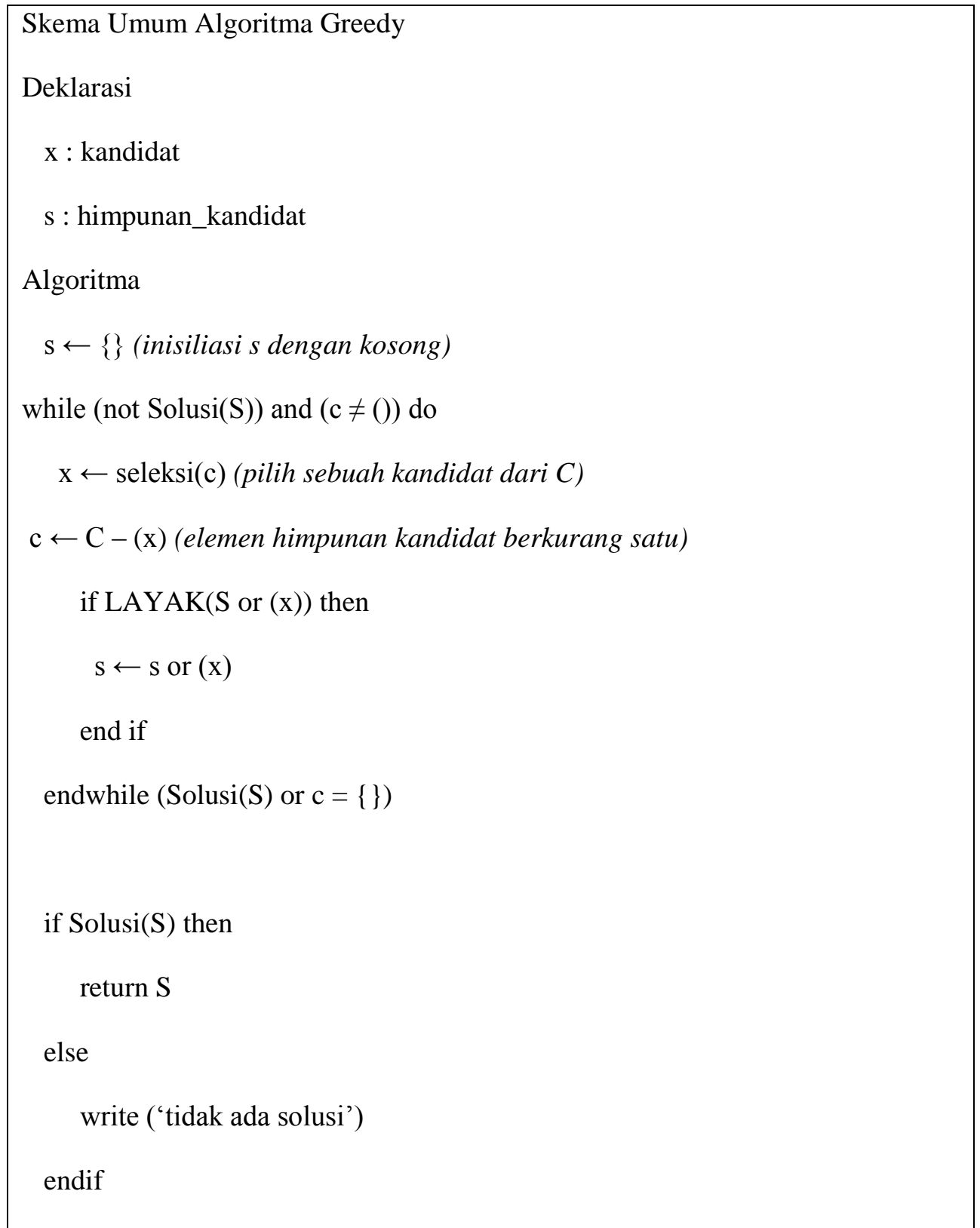

Gambar 2.1 Gambaran Umum Algoritma Greedy

Berikut terdapat diagram umum algoritma greedy yang menggambarkan bagaimana algoritma greedy memilih pilihan (titik) yang tersedia dan memenuhi syarat. 


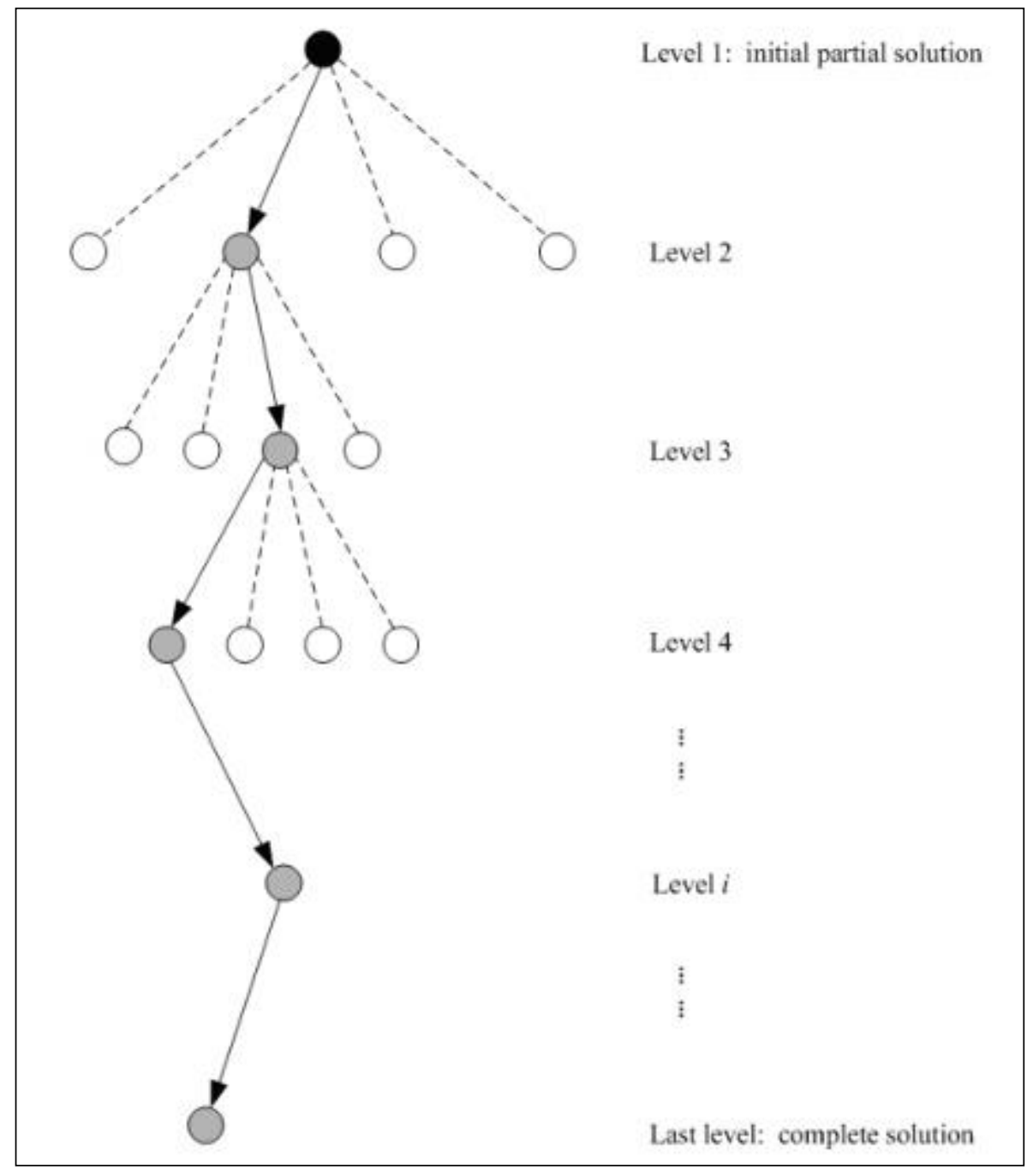

Gambar 2.2 Diagram Algoritma Greedy

Untuk beberapa masalah, akan ada banyak sekali jumlah titik untuk dicari. Oleh karena itu, dengan fungsi filtering ini maka akan mengurangi beban yang harus dicari ketika memilih pilihan yang tersedia. Pada proses filtering maka titik yang memenuhi syarat akan dipilih dan yang tidak sesuai akan dibuang secara permanen, titik-titik yang tersisa inilah yang akan digunakan pada saat proses penjalanan algoritma greedy. 


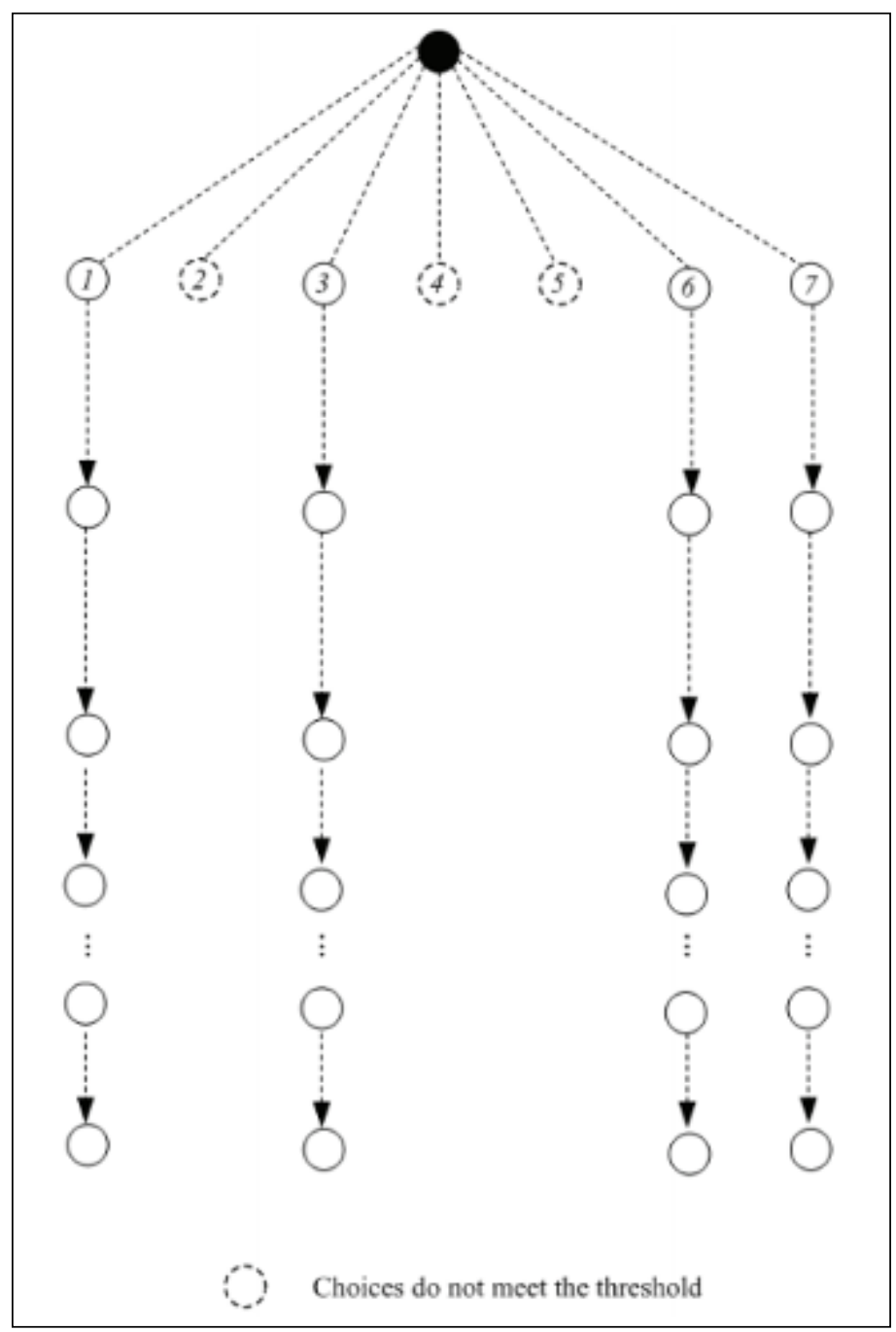

Gambar 2.3 Diagram Algoritma Greedy dengan Filtering

\section{HASIL DAN PEMBAHASAN}

Dari analisis dan perancangan sistem yang sudah dilakukan, Penulis mengangkat sebuah studi kasus yang terjadi pada tempat penelitian yaitu Sekolah Tinggi Teknologi Indonesia Tanjungpinang yaitu pada tanggal 21 Desember 2016. Pada saat itu memiliki elemen-elemen sidang yaitu:

Tabel 1 : Tabel Dosen Penguji

\begin{tabular}{|l|l|l|}
\hline Kode Dosen & \multicolumn{1}{|c|}{ Nama Dosen } & \multicolumn{1}{c|}{ Bagian } \\
\hline AW & Ade Winarni, MT & $\begin{array}{l}\text { Pra } \\
\text { sidang/Skripsi }\end{array}$ \\
\hline
\end{tabular}




\begin{tabular}{|l|l|l|}
\hline RR & Moch. Rizki Romdoni, S.KOM, MT & $\begin{array}{l}\text { Pra } \\
\text { sidang/Skripsi }\end{array}$ \\
\hline WH & Wanhendra Manihuruk., M.SI & $\begin{array}{l}\text { Pra } \\
\text { sidang/Skripsi }\end{array}$ \\
\hline HM & Hetty Mulyani., ST., M.Kom & $\begin{array}{l}\text { Pra } \\
\text { sidang/Skripsi }\end{array}$ \\
\hline SU & Drs. H. Mohm. Saleh. H. Umar, MM & Tata Tulis \\
\hline EV & Dra. Hj. Elvianna., MM & Tata Tulis \\
\hline DD & Dedy Jauhari, S.Kom., MM & Tata Tulis \\
\hline FZ & Muhammad Faizal, SH., MM & Tata Tulis \\
\hline LF & Lois Frederik, SE., SH., MM & Tata Tulis \\
\hline LS & Liza Safitri., ST., M.Kom & $\begin{array}{l}\text { Pra } \\
\text { sidang/Skripsi }\end{array}$ \\
\hline DN & Dwi Nurul Huda., ST., M.Kom & $\begin{array}{l}\text { Pra } \\
\text { sidang/Skripsi }\end{array}$ \\
\hline DJ & Jajang Nurjaman., ST & Kerja Praktek \\
\hline JJ & Danandjaya Saputra., ST & Kerja Praktek \\
\hline AG & Naktek \\
\hline
\end{tabular}

Tabel 2 : Ruangan Sidang

\begin{tabular}{|c|}
\hline Kode Ruangan \\
\hline A201 \\
\hline A202 \\
\hline A203 \\
\hline A305 \\
\hline B201 \\
\hline
\end{tabular}




\begin{tabular}{|c|}
\hline B301 \\
\hline
\end{tabular}

Tabel 3 : Waktu Sidang

\begin{tabular}{|c|}
\hline Waktu Sidang \\
\hline $09.00-10.00$ \\
\hline $10.00-11.00$ \\
\hline $11.00-12.00$ \\
\hline $13.00-14.00$ \\
\hline $14.00-15.00$ \\
\hline $15.00-16.00$ \\
\hline $16.00-17.00$ \\
\hline
\end{tabular}

Tabel 4 : Jumlah Mahasiswa Sidang

\begin{tabular}{|l|c|}
\hline \multicolumn{1}{|c|}{ Jenis Sidang } & Jumlah \\
\hline Kerja Praktek & 10 \\
\hline Pra Sidang & 6 \\
\hline Skripsi & 16 \\
\hline
\end{tabular}


Misalkan dosen yang dapat hadir pada hari tersebut adalah

Tabel 5 : Tabel Dosen yang dapat hadir

\begin{tabular}{|l|l|l|c|}
\hline Kode & \multicolumn{1}{|c|}{ Nama Dosen } & \multicolumn{1}{|c|}{ Bagian } & Hadir \\
\hline AW & Ade Winarni, MT & Pra sidang/ Skripsi & $\checkmark$ \\
\hline RR & Moch. Rizki Romdoni, S.KOM, MT & Pra sidang/ Skripsi & $\checkmark$ \\
\hline SU & Drs. H. Mohm. Saleh. H. Umar, MM & Tata Tulis & $\checkmark$ \\
\hline LS & Liza Safitri., ST M.Kom & Pra sidang/ Skripsi & $\checkmark$ \\
\hline DN & Dwi Nurul Huda., ST M.Kom & Pra sidang/ Skripsi & $\checkmark$ \\
\hline EV & Dra. Hj. Elvianna., MM & Tata Tulis & $\checkmark$ \\
\hline DD & Dedy Jauhari, S.Kom., MM & Tata Tulis & $\checkmark$ \\
\hline WH & Wanhendra Manihuruk., M.SI & Pra sidang/ Skripsi & $\checkmark$ \\
\hline HM & Hetty Mulyani., ST M.Kom & Pra sidang/ Skripsi & $\checkmark$ \\
\hline DJ & Danandjaya Saputra., ST & Kerja Praktek & $\checkmark$ \\
\hline AG & Ardianto Wibowo., ST & Kerja Praktek & $\checkmark$ \\
\hline
\end{tabular}

Syarat Penjadwalan itu sendiri adalah

1. Dosen penguji dan mahasiswa tidak boleh berada pada 2 ruangan yang berbeda pada waktu yang sama.

2. Mahasiswa tidak boleh muncul lebih dari satu kali pada sebuah acara sidang dan seluruh mahasiswa yang terdaftar harus dapat mengikuti acara sidang.

3. Dosen penguji KP harus minimal memiliki jenjang pendidikan S1 dengan jumlah 1 dosen, penguji pra sidang harus 2 dosen dan masingmasing merupakan dosen penguji pemrograman dan tata tulis, dan dosen penguji skripsi merupakan 2 dosen dengan minimal bergelar S2.

4. Dosen penguji tidak boleh menguji mahasiswa bimbingannya.

5. Durasi sidang seorang mahasiswa adalah 1 jam, sehingga terdapat 6 atau 7 jam sidang.

Langkah-langkah yang dilakukan untuk menghasilkan jadwal dengan algoritma greedy adalah: 
1. Menghitung jumlah waktu dan jumlah kelas yang dapat dilaksanakan sebagai acara sidang.

2. Mencari dan memilih salah satu mahasiswa yang mendaftarkan diri mengikuti sidang dengan tingkat prioritas dari pertama hingga akhir yaitu; Skripsi, Pra sidang, dan Kerja Praktek

3. Mencari dosen yang mengikuti acara sidang dan tidak sedang menguji mahasiswa lain, serta yang memenuhi syarat untuk menguji mahasiswa dan status dosen akan diganti statusnya ke "Sibuk" dan mengulang dari langkah 3 untuk mahasiswa lainnya.

4. Apabila tidak ada dosen yang dapat menguji mahasiswa tersebut, maka statusnya akan menjadi "Skip" dan diganti dengan mahasiswa lainnya, dan akan diikutsertakan pada generasi berikutnya setelah ada pergantian jam.

5. Apabila ada pergantian ruangan, maka seluruh dosen akan menjadi "Tidak Sibuk".

Berikut merupakan informasi berapa kali algoritma greedy diimplementasikan beserta elemen-elemen yang digunakan dengan jumlah berapa kali menghasilkan jadwal yang tidak sempurna:

Percobaan Pertama:

Sidang tanggal 28 September 2017

Dosen Kerja Praktek: 3

Dosen Tata Tulis: 1

Dosen Skripsi: 4

Mahasiswa Kerja Praktek: 6

Mahasiswa Prasidang: 6

Mahasiswa Skripsi: 16

Jumlah Ruangan: 6

Jumlah Waktu: 7

Hasil tanggal sidang adalah 1 hari, dan tidak ada mahasiswa yang belum mendapatkan jadwal sidang.

Percobaan Kedua:

Sidang tanggal 28 September 2017

Dosen Kerja Praktek: 3

Dosen Tata Tulis: 1

Dosen Skripsi: 3

Mahasiswa Kerja Praktek: 6

Mahasiswa Prasidang: 6

Mahasiswa Skripsi: 16

Jumlah Ruangan: 6

Jumlah Waktu: 7

Hasil tanggal sidang adalah 2 hari, dan tidak ada mahasiswa yang belum mendapatkan jadwal sidang. 
Percobaan Ketiga:

Sidang tanggal 24 Agustus 2017

Dosen Kerja Praktek: 4

Dosen Tata Tulis: 2

Dosen Skripsi: 5

Mahasiswa Kerja Praktek: 18

Mahasiswa Prasidang: 8

Mahasiswa Skripsi: 28

Jumlah Ruangan: 6

Jumlah Waktu: 7

Hasil tanggal sidang adalah 2 hari, dan tidak ada mahasiswa yang belum mendapatkan jadwal sidang.

Percobaan Keempat:

Sidang tanggal 24 Agustus 2017

Dosen Kerja Praktek: 2

Dosen Tata Tulis: 1

Dosen Skripsi: 4

Mahasiswa Kerja Praktek: 18

Mahasiswa Prasidang: 8

Mahasiswa Skripsi: 28

Jumlah Ruangan: 6

Jumlah Waktu: 8

Hasil tanggal sidang adalah 2 hari, dan tidak ada mahasiswa yang belum mendapatkan jadwal sidang.

Percobaan Kelima:

Sidang tanggal 24 Agustus 2017

Dosen Kerja Praktek: 2

Dosen Tata Tulis: 1

Dosen Skripsi: 4

Mahasiswa Kerja Praktek: 18

Mahasiswa Prasidang: 8

Mahasiswa Skripsi: 28

Jumlah Ruangan: 6

Jumlah Waktu: 7

Hasil tanggal sidang adalah 2 hari, dan terdapat 2 mahasiswa yang masih belum mendapatkan jadwal sidang sehingga harus generate ulang. 


\section{KESIMPULAN}

Dari hasil penelitian yang telah dilakukan secara umum, sistem yang diterapkan merupakan pengembangan dari sistem yang telah ada. Dengan dibangunnya aplikasi pembuatan jadwal sidangini, pengguna berharap mampu melakukan proses yaitu sebagai berikut:

1. Proses pembuatan jadwal sidang lebih mudah, cepat dan sudah terkomputerisasi.

2. Hasil jadwal sidang sudah tidak ada lagi bentrokan antar dosen dan mahasiswa.

Selain melakukan skripsi baik dalam penelitian maupun pengerjaan pembuatan Aplikasi Pembuatan Jadwal Sidang KP, Pra sidang, dan Skripsi penulismemiliki beberapa saran yaitu sebagai berikut:

1. Aplikasi tersebut dapat digunakan atau ditampilkan lebih baik dan menarik ketika ditampilkan pada handphone atau smartphone.

2. Aplikasi dapat dikembangkan di perangkat berbasis Android.

3. Aplikasi terdapat halaman bantuan yang memudahkan pengguna.

\section{DAFTAR PUSTAKA}

Bertzzie. Algoritma Greedy - Analisis Algoritma didapat dari: https://bertzzie.com/ knowledge/analisis-algoritma/Greedy.html

Chen Mao, A Greedy Algorithm with Forward-Looking Strategy, Wuhan: INTECH Open Access Publisher, 2008

IT-Jurnal. Pengertian Algoritma Greedy didapat dari: https://www.it-jurnal.com/ pengertian-algoritma-greedy/

Sekolah Tinggi Teknologi Indonesia, Buku Panduan Akademik 2014 STTI, 2014

STT Indonesia Tanjungpinang didapat dari: http://www.sttindonesia.ac.id

Wahyuni. Penjadwalan dengan teknik sisipan (Insertion Technique) didapat dari http://repository.usu.ac.id/bitstream/handle/123456789/1460/tindustridini2.pdf.txt?sequence $=3$ 
